\title{
Harapan Polisi di Kota Bandung terhadap Pembuatan Visum Klinik
}

\author{
Fadly Aufar Saptadirja', Yoni Fuadah Syukriani², Wulan Mayasari ${ }^{3}$
}

${ }^{1}$ Fakultas Kedokteran, Universitas Padjadjaran

${ }^{2}$ Departemen Ilmu Kedokteran Forensik dan Medikolegal, Fakultas Kedokteran Universitas Padjadjaran/ Rumah Sakit Umum Pusat Dr. Hasan Sadikin, Bandung

${ }^{3}$ Departemen Anatomi, Fisiologi, dan Biologi Sel, Fakultas Kedokteran Universitas Padjadjaran/Rumah Sakit Umum Pusat Dr. Hasan Sadikin, Bandung,

\begin{abstract}
Abstrak
Visum et Repertum (VeR) merupakan salah satu dari lima alat bukti yang sah dalam pembuktian hukum. Pembuatan VeR sampai sekarang belum mempunyai standardisasi yang jelas, sehingga dibutuhkan adanya evaluasi pembuatan VeR. Evaluasi pembuatan VeR berdasarkan dari masalah-masalah yang ditemukan polisi dalam permintaan pembuatan VeR yang kemudian digunakan sebagai saran perbaikan pembuatan VeR terutama pembuatan VeR klinik. Penelitian ini bertujuan untuk mengetahui harapan polisi di Kota Bandung terhadap pembuatan VeR klinik. Penelitian ini menggunakan desain deskriptif kualitatif dengan cara wawancara mendalam kepada enam orang polisi yang telah memenuhi kriteria inklusi dan eksklusi di Kepolisian Wilayah Kota Besar (Polwiltabes) Kota Bandung sejak bulan Agustus sampai Desember 2016. Hasil penelitian ini menunjukkan bahwa polisi mengalami kesulitan dalam memahami bahasa yang digunakan dalam visum, dokter kurang responsif dalam pembuatan visum, dan tidak terdapat standar waktu untuk memproses pembuatan visum. Temuan lainnya adalah terdapat penolakan visum dari pihak rumah sakit karena korban sudah mendapatkan pengobatan di tempat lain dan keterlambatan surat izin serta tidak jelasnya alur pendanaan permintaan visum. Berdasarkan hasil tersebut, polisi berharap dokter dan instansi kesehatan dapat memperbaiki masalah yang ditemukan. Perbaikan tersebut berdasarkan standar operasional prosedur (SOP), panduan World Health Organization (WHO) dan hukum yang berlaku di Indonesia.
\end{abstract}

Kata Kunci : Dokter, Harapan polisi, Visum

\section{Police Expectancy in Bandung City to Doctor's Clinical Visum}

\begin{abstract}
Visum et Repertum (VeR) is one of 5 valid evidences in legal proofing. The making of VeR still has no clear standardization until now, so an evaluation of VeR making is needed. The evaluation of Ver creation is based on problems found by police when requesting VeR creation which then used as advice to improve VeR creation especially clinical VeR creation. This research aims to find out police's hopes in Bandung City towards clinical VeR creation. This descriptive qualitative research collected data by in-depth interview to 6 policemen which fulfilled inclusion and exclusion criteria in Kepolisian Wilayah Kota Besar (Polwiltabes) of Bandung City since August to December 2016. The result of the research showed that police experienced difficulties in understanding the languages used in visum, doctors lacked responsiveness in visum creation, and there's no time standard to process visum creation. Other foundings were there were visum rejections from hospitals because the victim had received treatment in other places and tardiness of permit letter also the unclear funding procedure of visum request. Based on those results police hoped that doctors and health instances can fix those problems. Those fixes are based on standard operating procedure (SOP), World Health Organization (WHO) guide, and Indonesian law.
\end{abstract}

Keywords : Doctor, Police expectancy, Visum

Korespondensi:

Fadly Aufar Saptadirja

Fakultas Kedokteran, Universitas Padjadjaran

Jl. Raya Bandung-Sumedang km 21 Jatinangor

Mobile : 0818232600

Email :fadlyaufars@gmail.com 


\section{Pendahuluan}

Menurut Kamus Besar Bahasa Indonesia, Visum et Repertum (VeR) adalah kesaksian dari tenaga ahli; surat keterangan seorang dokter atau tenaga ahli lainnya yang sejenis yang berisi simpulan suatu pemeriksaan yang telah dilakukannya sesuai dengan profesi dan keahlian yang dimiliki. Penafsiran lain VeR oleh R. Atang Ranoemihardja menyatakan bahwa pengertian yang terkandung dalam VeR ialah yang "dilihat" dan "ditemukan", VeR adalah suatu keterangan dokter tentang apa yang dilihat dan diketemukan dalam melakukan terhadap orang luka atau mayat, dan merupakan kesaksian tertulis. ${ }^{1}$ Pengertian lain disampaikan oleh sofyan, VeR merupakan suatu laporan tertulis dari ahli dokter yang dibuat berdasarkan sumpah, perihal apa yang dilihat dan diketemukan atas bukti hidup, mayat atau fisik ataupun barang bukti lain, kemudian dilakukan pemeriksaan berdasarkan pengetahuan yang sebaik-baiknya. ${ }^{2}$ Definisi VeR sendiri secara implisit tidak diatur dalam KUHAP, tetapi diatur dalam LembarNegara nomor 350 tahun 1937 yang menjelaskan bahwa VeR adalah "laporan tertulis untuk yustisi yang dibuat oleh dokter berdasarkan sumpah tentang segala hal yang dilihat dan ditemukan pada benda yang diperiksa menurut pengetahuannya dengan sebaik-baiknya". ${ }^{3}$

VeR merupakan salah satu dari lima alat bukti yang sah dalam pembuktian tindak pidana.,7,9 Secara garis besar VeR terbagi menjadi tiga jenis yaitu VeR korban hidup, VeR jenazah dan VeR psikiatrik (kejiwaan). Dalam praktik, VeR korban hidup dan VeR psikiatrik dikelompokan sebagai VeR klinik. ${ }^{3,5}$ VeR untuk korban hidup atau VeR klinik mempunyai banyak macam perkara contoh kekerasan rumah tangga, child abused and neglect, tindak pemerkosaan, tindak penganiayaan dan juga tentang kejiwaan. Dalam praktik, dokter melakukan tindak medis bukan hanya untuk kepentingan diagnosis dan pengobatan penyakit saja tetapi juga membuat surat keterangan medis untuk membuktikan apa yang terjadi. Surat keterangan medis atau VeR digunakan dalam pembuktian tindak pidana. VeR klinik yang baik harus mampu membuat terang perkara tindak pidana yang terjadi dengan melibatkan bukti-bukti forensik yang cukup. ${ }^{6-8}$ Pembuatan VeR harus menggunakan surat tertulis dari penyidik dan diajukan khusus kepada dokter untuk melakukan pemeriksaan. ${ }^{9}$

Pembuatan VeR harus dilakukan oleh dokter yang telah disumpah jabatan terhadap pemeriksaan.4,10,11 Pembuatan VeR oleh dokter harus melalui surat resmi dari penyidik Kepolisian Republik Indonesia (Polri) yang ditandatangani minimal oleh Inspektur Polisi Dua (IPDA). ${ }^{9,12}$
Surat permintaan VeR tersebut harus diantar oleh petugas kepolisian dan hasilnya diserahkan langsung kepada penyidik. Salinan visum tidak boleh diserahkan kepada siapapun. ${ }^{9}$ Selain penyidik Polri, instansi lain yang berwenang meminta VeR adalah hakim, jaksa penyidik, dan jaksa penuntut umum. ${ }^{9}$

Sebelum tindakan pemeriksaan untuk pembuatan VeR perlu dijelaskan proses, manfaat, dan risiko pemeriksaan bagi korban sehubungan dengan perkara pidananya serta dihubungkan dengan upaya pengobatan bagi korban yang dituangkan dalam informed consent. Apabila korban menolak untuk diperiksa maka dokter meminta pernyataan tertulis tentang penolakan dari korban disertai alasannya atau mencatatnya didalam rekam medis. ${ }^{9}$ VeR dibuat atas permintaan penyidik.

Permintaan pembuatan VeR harus atas permintaan penyidik. Dalam proses penyidikan jika terdapat masalah pencarian bukti, penyidik dapat meminta bantuan langsung dari dokter. Penyelidikan dilakukan oleh polisi untuk menentukan suatu kasus termasuk kasus pidana atau bukan. Setelah diduga kasus pidana, proses penyidikanpun dilakukan untuk melakuan pencarian bukti guna menemukan tersangka. Setelah sudah cukup bukti, jaksa sebagai yang diberi wewenang oleh undang-undang akan melakukan penuntutan. Kemudian hakim mengadili tersangka dan menghasilkan putusan pengadilan. Hasil putusan dapat dipengaruhi oleh lima alat bukti berupa keterangan saksi, keterangan ahli, surat, petunjuk, dan keterangan terdakwa. Hakim tidak boleh menjatuhkan pidana kepada seseorang kecuali apabila disertai dengan sekurang-kurangnya dua alat bukti yang sah sampai ia memperoleh keyakinan bahwa suatu tindak pidana benar-benar terjadi dan bahwa terdakwalah yang bersalah. Keterkaitan dokter dalam memberikan bantuan terhadap peradilan terdapat dalam dua alat bukti dari lima alat bukti yang sah yaitu dalam pembuatan surat dan keterangan ahli. Dalam pembuatan VeR dokter dapat diminta oleh penyidik, penasihat hukum, dan hakim. ${ }^{4}$

Berdasarkan studi pendahuluan yang peneliti lain lakukan, dapat terjadi perbedaan penulisan laporan VeR antar institusi. Misalnya, jika dibandingkan antara VeR berdasarkan Prosedur Standar Operasional Pelaksanaan Standar Pelayanan Minimal (SPM) yang diterbitkan Kementrian Pemberdayaan Perempuan dan Perlindungan Anak Republik Indonesia dengan VeR dari Rumah Sakit Hasan Sadikin Bandung (RSHS) terdapat perbedaan cara pembuatan. VeR dari RSHS terdapat detail tentang emosional pasien, pemeriksaan fisik yang lengkap dan 
terstruktur dari kepala hingga kaki, sedangkan yang berasal dari SPM yang diterbitkan Kementrian Pemberdayaan Perempuan dan Perlindungan Anak Republik Indonesia hanya menuliskan spesifik temuan dari pasien di bagian pemberitaan. Akan tetapi, VeR dari RSHS tidak mencantumkan anamnesis terhadap pasien dan penampilan pasien saat pemeriksaan. Pembuatan VeR oleh setiap instansi kesehatan dari tingkat pertama sampai tingkat ketiga tidak mempunyai standar dalam pembuatan. Hanya berdasarkan kebijakan dari masing-masing instansi. Perbedaan ini menyebabkan pengguna VeR seperti polisi yang melakukan penyidikan dapat mengalami perbedaan atau kesalahan dalam memaknai makna VeR. ${ }^{7,9}$

Berdasarkan hal-hal tersebut, maka dapat disimpulkan bahwa perlu dilakukan penelitian untuk mengetahui harapan polisi di Bandung terhadap pembuatan visum klinik oleh dokter. Penelitian ini ingin digunakan sebagai bahan mengevaluasi pembuatan VeR selama ini, yang selanjutnya diharapkan dapat membantu dalam pembuatan standar VeR. Akan tetapi, penelitian ini jarang dilakukan sehingga bahan rujukan minimal. Sehingga penelitian ini diharapkan dapat menambahkan khasanah keilmuan.

\section{Metode}

Penelitian ini dilakukan dari bulan Agustus Desember 2016 di Polwiltabes Kota Bandung menggunakan desain deskriptif kualitatif. Subjek penelitian adalah enam orang polisi dengan kriteria inklusi berupa pernah meminta, membantu permintaan, dan membaca visum. Kriteria eksklusi berupa polisi yang menolak ikut serta dalam penelitian ini. Jumlah minimal sampel yang dibutuhkan pada penelitian ini tidak ada, hanya ditentukan berdasarkan rumus penelitian deskriptif kualitatif untuk mencapai sampel jenuh. Pengambilan data dilakukan dengan cara wawancara mendalam, sudah dibuat terlebih dahulu surat pembebasan etik dari Komisi Etik Penelitian Kesehatan Fakultas Kedokteran Universitas Padjadjaran dan surat izin penelitian dari Polwiltabes Kota Bandung. Data hasil wawancara selanjutnya diolah dengan cara traskripsi suara menjadi bentuk tulisan (verbatim), scanning, merangkum dan memilih data, reduksi, menyusun sesuai jenis data, dan yang terakhir dilakukan koding berdasarkan kategori dan tema. Validasi data dilakukan dengan triangulasi oleh salah satu dokter forensik dan salah satu petinggi polisi (kepala satuan) dan member checking. Data akhir kemudian dibuat dalam bentuk deskripsi. Penelitian ini sebelumnya telah mendapatkan persetujuan etik dari Komisi Etik Penelitian Kesehatan Universitas Padjadjaran (nomor registrasi 0116060669 dan nomor pesetujuan etik No: 576/UN6.C1.3.2/KEPK/PN2016).

\section{Hasil}

Telah dilakukan wawancara dengan 6 responden A, B, C, D, E, dan F. A merupakan anggota polisi dengan pangkat Brigadir Dua (Bripda), B berpangkat Brigadir, C berpangkat Ajun Inspektur Polisi Satu (AIPTU), D berpangkat Brigadir Dua (Bripda), E berpangkat Brigadir, dan F berpangkat Brigadir. Dan telah dilakukan triangulasi dengan salah satu petinggi polisi dan dokter forensik yang diberi inisial $G$ dan $\mathrm{H}$. Berdasarkan opini polisi, terdapat lima hal yang perlu ditingkatkan dalam proses pembuatan visum yaitu bahasa yang digunakan dalam visum, kecepatan pembuatan visum, respons dokter atau instansi kesehatan terhadap pembuatan visum, perizinan pembuatan visum, dan pendanaan untuk pembuatan visum.

1. Bahasa yang digunakan dalam visum; Hasil wawancara dengan polisi terdapat bahasa yang tidak dapat dipahami sehingga dapat menimbulkan masalah seperti kesulitan untuk menemukan pasal yang sesuai dan membutuhkan waktu lebih lama untuk menanyakan kembali ke dokter ataupun instansi kesehatan terkait tentang mengenai maksud dari kalimat yang tertulis di visum. Seperti salah satu kutipan kalimat dari salah satu narasumber:

"Banyak sekali bahasa-bahasa yang tidak dimengerti oleh anggota hukum karena bahasa yang digunakan atau yang tercantum dalam visum itu bahasa kedokteran. Jadi, susah banget untuk... iya, orang umum untuk mengerti" (polisi E).

Hal ini disetujui oleh salah satu petinggi divisi Satuan Reserse Kriminal (SATRESKRIM) bahwa bahasa itu sangat penting dan lebih baik dijelaskan dalam bahasa umum agar mudah dipahami.

"iya sepengalaman saya bahasa yang digunakan adalah bahasa kedokteran dan memang bahasa itu sangat penting dalam penentuan pasal pasal apa saja yang ditujukan untuk tuntutan...." (polisi G)

Opini ini disetujui oleh salah satu dokter forensik penggunaan bahasa yang digunakan dalam visum harus mudah dimengerti oleh penggunanya.

"penggunaan bahasa dalam visum harus membuat mengerti penggunanya, bisa digunakan dengan bahasa indonesia ataupun bahasa yang dimengerti oleh orang sekitar seperti bahasa daerah." (dokter H) 
2. Kecepatan pembuatan visum; Hasil wawancara narasumber menunjukkan masih terdapat masalah dalam kecepatan pembuatan visum. Setiap instansi kesehatan tidak memiliki standar waktu pembuatan visum yang sama. Hal ini sesuai dengan salah satu opini narasumber:

"....terkait hasil visum sendiri tergantung dari seberapa cepat dokter kehakiman dalam hal ini forensik yang ada di rumah sakit itu sendiri memproses visum ini, jika kita bandingkan antara Rumah Sakit Hasan Sadikin (RSHS) dengan forensik dokter Sartika Asih itu perbedaan waktunya cukup signifikan, jika di RSHS bisa sampai satu bulan karena mungkin ya, terlalu banyak birokrasi yang dilalui tapi kalau di Sartika Asih sendiri itu sekitar satu minggu dan di rumah sakit umum lainnya sekitar satu minggu." (polisi F)

Hal ini disetujui oleh salah satu petinggi divisi SATRESKRIM bahwa instansi kesehatan tidak memiliki standardisasi waktu pembuatan visum.

"iya begitulah dulu, sebelum Rumah Sakit Sartika Asih lengkap seperti sekarang yang sudah dilengkapi dokter forensik kita meminta visum ke banyak rumah sakit, tapi sekarang lebih di tujukan kesana, karena disana prosesnya lebih cepat dan kami di pihak kepolisian juga lebih mudah menghubungi dan dihubungi oleh rumah sakit. Kalau dulu di RSHS terutama untuk otopsi bisa lebih dari satu bulan. (polisi G)

Opini ini diperkuat oleh pendapat dari dokter forensik bahwa banyak faktor yang memengaruhi kecepatan pembuatan visum.

"banyak faktor yang memengaruhi kecepatan dari pembuatan visum di rumah sakit mulai dari proses pemindahan medrec menjadi visum, adminitstrasi (seperti penelusuran medrec jika dirawatlama), kelengkapan darimedrec itu sendiri, kemampuan dokter, jumlah permintaan visum dan sumber daya manusia (dokter, administrasi maupun team dokter yang menangani) itu dapat memengaruhi pembuatan visum. (dokter $\mathrm{H}$ )

Opini lain juga disampaikan dari dokter forensik bahwa kecepatan pembuatan visum di RSHS sudah memiliki SOP (kurang dari dua puluh hari).

" seingat saya RSHS sudah memiliki SOP pembuatan visum kurang dari dua puluh hari, akan tetapi jika permintaan di follow up atau urgensi nya tinggi bisa dipercepat."'(dokter $\mathrm{H}$ )

3. Respon dokter atau rumah sakit terhadap permintaan visum; Hasil wawancara narasumber menunjukkan bahwa terdapat masalah antara hubungan polisi dengan instansi kesehatan ataupun dengan dokter yang mengerjakan visum sehingga dalam beberapa kasus dapat memperlambat waktu untuk memperoleh hasil visum. Masalah antara hubungan polisi dengan instansi kesehatan terdapat di beragam jenjang.

Pendapat berikut adalah respon dokter kurang responsif terhadap permintaan visum.

"kesulitan yang dialami selama visum atau memohonkan visum sampai saat ini di Rumah Sakit Umum Bandung atau Sartika Asih tidak ada tetapi terkait dengan di RSHS terkadang penyidik atau dokter ataupun paramedis disana kurang responsif terkait dengan permintaan visum itu sendiri, sehingga sangat jarang penyidik pembantu ataupun penyidik dari SATRESKRIM Polrestabes memintakan visum ke Hasan Sadikin jika itu menyakup tentang visum selain autopsi yah, kalo autopsi mau ga mau pasti di Hasan Sadikin atau di Sartika Asih gitu ya." (polisi F).

Pendapat kedua adalah respon instansi kesehatan yang terdapat masalah.

".......Nah gitu, saya juga punya pengalaman saya mengantar korban visum masih ada bekas luka masih ada bekas memar kemudian karena korban tersebut pernah berobat ke rumahsakit lain sehingga akhirnya rumah sakit menolak, saya bersikeras untuk agar visum itu diterima oleh rumah sakit tersebut....." (polisi A)

Opini ini diperkuat oleh pendapat dari dokter forensik bahwa sering kali dokter kurang responsif menanggapi visum.

“... saya akui dokter sering kali kurang responsif terhadap visum dikarenakan beberapa dokter merasa malas untuk berhubungan dengan polisi, takut untuk berhubungan dengan polisi, kurang mengerti hukum, dan takut berurusan dengan hukum."

4. Perizinan permintaan visum; Hasil wawancara narasumber menunjukkan bahwa terdapat masalah dalam perizinan permintaan visum terkait keterlambatan surat, penolakan secara sepihak ataupun menolak karena sudah menerima pengobatan dari tempat lain. Masalah perizinan ini dapat menghambat polisi untuk segera mendapatkan hasil visum. Opini ini berdasarkan kutipan tersebut.

"......saya mengantar korban visum masih ada bekas luka masih ada bekas memar kemudian karena korban tersebut pernah berobat ke rumah sakit lain sehingga akhirnya rumah sakit menolak, saya bersikeras untuk agar visum itu diterima oleh rumah sakit tersebut, saya sempat ada debat dulu yah sama pihak rumah sakit memakan waktu juga. kemudian akhirnya pihak rumah sakit memutuskan untuk visum, namun pihak rumah sakit mengatakan bahwa kami akan mevisum korban namun tetap di hasil visum itu tidak ada luka memar, tidak ditemukan luka memar walaupun pada kenyataannya sekarang korban masih memiliki luka memar. Nah itukan berarti sudah, saya sih yah saya melihat dari dari bukti gitu yah. Itukan sudah jelas tampak 
gitu ada bekas lukanya. Kemudian dia bilang kepihak kami kalau pihak rumah sakit akan mengeluarkan, melakukan visum tapi dari hasil visum tersebut akan dikeluarkan tidak ada luka atau memar...."(polisi A)

Pendapat lain disampaikan berdasarkan kutipan berikut.

"untuk kesulitannya itu berkaitan dengan proses permohonannya itu yah minimal 1×24 jam itu kan, sementara banyaknya kendala itu si pelapor atau korban itu melaporkan lebih dari 1x24 jam kaitan suatu tindak pidana, sementara dia prosesnya itu dia lebih cenderung melakukan perawatan keterkaitan luka atau ehh penyebab dari tindak pidana itu sendiri, jadi kendalanya kita pihak rumah sakit itu sendiri tidak mau menerima apabila melebihi 1x24 jam." (polisi C)

5. Pendanaan untuk permintaan visum; Hasil wawancara narasumber menunjukkan bahwa sering kali permintaan visum dan penanganan yang dialami oleh korban terkadang ditanggung oleh polisi yang piket pada saat korban meminta visum. Berikut adalah kutipan polisi mengenai penangguhan yang ditanggung oleh polisi.

"Terkadang dana untuk visum dan pengobatan dilimpahkan kepada polisi yang ada di piket."(polisi C)

Opini ini disetujui oleh salah satu petinggi divisi SATRESKRIM bahwa pendanaan permintaan visum terkadang ditanggung oleh polisi yang sedang piket.

"iya itu benar, biasanya piket itu yang nanggung contoh kalo ada perkelahian antar gang itukan mereka ga punya uang habis itu lapor dan kita yah bikin laporan visum kan. Yang bayar siapa? Mereka emang selalu punya uang gitu?"(polisi G).

Opini ini diperjelas oleh salah satu dokter forensik bahwa pendanaan seharusnya ditanggung oleh Anggaran Pendanaan dan Belanjaan Daerah (APBD) atau Anggaran Pendanaan dan Belanja Negara (APBN).

"untuk masalah pendanaan sudah diatur jelas yah di KUHAP bahwa semua pemeriksaan ditanggung oleh negara dan dijelaskan secara rinci di UU Kesehatan bahwa ditanggung oleh APBD atau APBN, kalo sekarang sudah bisa ditanggung BPJS.” (dokter H).

\section{Pembahasan}

Hasil penelitian ini menunjukan bahwa penggunaan bahasa di dalam visum harus diperjelas agar membuat terang suatu perkara. Hasil ini ditegaskan oleh penelitian Tia Dewi yang menunjukan penggunaan alat bukti dengan menginterpretasi yang salah dapat menyebabkan kematian orang lain dalam kasus pembuktian di pengadilan negeri Surakarta. Alat bukti yang digunakan adalah keterangan saksi, alat bukti surat berupa VeR, dan keterangan terdakwa. ${ }^{12}$ Literatur lain menegaskan bahwa VeR yang baik harus membuat terang perkara tindak pidana yang terjadi dengan melibatkan bukti-bukti forensik yang cukup. ${ }^{13}$ Penelitian Thomas Grisso menegaskan ada sepuluh kesalahan yang sering terjadi dan salah satunya adanya masalah dalam bahasa yang sering menggunakan bahasa khusus, istilah, dan bahasa yang tidak umum digunakan. ${ }^{14}$ Berdasarkan petunjuk World Health Organization (WHO) untuk medikolegal, bahwa penulisan dan pemberian bukti menggunakan bahasa yang mudah dimengerti dan tepat bagi pengguna bukti yaitu penegak hukum dan salah satunya adalah polisi. ${ }^{15}$

Hasil penelitian ini ditemukan dokter seharusnya lebih responsif dalam menerima permintaan visum dari polisi. Penelitian Dedi Afandi menyatakan bahwa praktisi kesehatan diharapkan agar dapat mengupayakan prosedur pembuatan VeR khususnya VeR perlukaan yang memenuhi standar karena memiliki dampak yuridis yang luas dan dapat menentukan nasib seseorang. ${ }^{13}$ Prosedur pembuatan laporan visum berdasarkan WHO dimulai dari awal penerimaan surat permintaan visum yang diberikan polisi, melakukan perizinan kepada pasien, pemeriksaan hingga penulisan laporan dan pemberian kesaksian. ${ }^{15}$ Berdasarkan penelitian Dedi Afandi dan WHO pemberian respon yang baik termasuk standar dalam pembuatan visum.

Penelitian ini menunjukan pentingnya pembuatan standar waktu pembuatan visum karena terdapat faktor perlambatan seperti perizinan yang rumit, tidak adanya dokter yang bertugas, dan penolakan sepihak dari rumah sakit. Hasil ini ditegaskan oleh penelitian di kota Yogyakarta bahwa faktor yang menyebabkan keterlambatan pembuatan visum adalah "man" yaitu kurangnya koordinasi dari petugas rumah sakit, jadwal dokter yang tidak tetap, petugas rekam medis terlalu lama dalam mengetik surat, dan Methode yaitu alur VeR tidak sesuai dengan prosedur tentang pembuatan surat keterangan VeR tahun $2010 .{ }^{16}$ Hal ini juga ditemukan oleh peneliti saat mewawancarai subjek tentang kecepatan permintaan visum bahwa terdapat faktor-faktor yang memperlambat penerimaan visum oleh polisi. Dengan adanya standar waktu maka dapat membuat sebuah instansi harus bertanggung jawab terhadap waktu yang dibutuhkan untuk membuat visum. Dengan adanya keterlambatan memperoleh visum dapat membuat masalah dalam penahanan tersangka, berdasarkan pasal 20 ayat 1 dan 2 Kitab Undang-Undang Hukum Acara 
Pidana (KUHAP) batas penahanan sementara pada proses penyidikan maksimal duapuluh hari dan dapat diperpanjang hingga empatpuluh hari. ${ }^{9}$ Berdasarkan KUHAP maka standar waktu harus kurang dari waktu penahanan sementara.

Penelitian ini menemukan masalah dalam perizinan dan hubungan antara polisi dengan instansi kesehatan karena adanya penolakan permintaan visum yang seharusnya tidak boleh adanya penolakan dalam permintaan visum. Hasil ini dibuktikan berdasarkan KUHAP pasal 179 ayat 1 yang tertulis "Setiap orang yang diminta pendapatnya sebagai ahli kedokteran kehakiman atau dokter atau ahli lainnya wajib memberikan keterangan ahli demi keadilan.", sehingga instansi kesehatan atau dokter tidak boleh menolak pembuatan visum. ${ }^{9}$ Berdasarkan Standar Prosedur Operasional (SPO) seharusnya masalah perizinan berupa penolakan yang diakibatkan oleh alasan sudah menerima pengobatan sebelumnya tetap diterima maupun terlambatnya surat perizinan yang disampaikan polisi seharusnya tetap diterima.?

Penelitian ini juga menemukan masalah lain berupa pendanaan untuk biaya permintaan visum dan pengobatan pasien dilimpahkan kepada polisi yang sedang piket yang seharusnya adalah tanggungan pemerintah melalui Anggaran Pemerintah dan Belanja negara (APBN) dan Anggaran Pemerintah dan Belanja Daerah (APBD). Hasil ini didasari KUHAP pasal 136 yang tertulis "Semua biaya yang dikeluarkan untuk kepentingan pemeriksaan sebagaimana dimaksud dalam Bagian Kedua Bab14 ditanggung oleh negara." ${ }^{\prime \prime} \mathrm{Hal}$ ini ditegaskan dalam UndangUndang Republik Indonesia Nomor 36 Tahun 2009 dalam pasal 125 bahwa "Biaya pemeriksaan kesehatan terhadap korban tindak pidana dan/atau pemeriksaan mayat untuk kepentingan hukum ditanggung oleh pemerintah melalui APBN dan APBD." 17 Sehingga segala asuransi kesehatan yang menggunakan APBD atau APBN dapat menanggung biaya permintan visum bukanlah polisi ataupun instansi kesehatan.

Keterbatasan dari penelitian ini yang harus diperhatikan yaitu sulitnya mewawancarai narasumber dengan pangkat minimal IPDA (Inspektur Polisi Dua). Hal ini dikarenakan jumlah narasumber yang tidak terlalu banyak dan pekerjaan narasumber yang banyak sehingga peneliti mewawancarai polisi yang mengerti visum dan ditunjuk langsung oleh salah satu petinggi SATRESKRIM.

Simpulan daripenelitian ini adalah visum sudah memenuhi harapan polisi meskipun ada beberapa hal yang perlu ditingkatkan yaitu Perlunya penggunaan bahasa yang mudah dipahami dalam pembuatan visum. Meningkatkan kerjasama polisi dengan instansi kesehatan ataupun dokter. Mempermudah proses perizinan permintaan visum. Membuat standardisasi pembuatan visum, dan Memperjelas aturan pendanaan untuk proses visum.

Rekomendasi penelitian ini adalah Perlu digunakannya bahasa yang umum dalam pembuatan visum. Peningkatkan hubungan antara instansi kesehatan dan polisi dengan cara mempermudah dan mengikuti Standar Operasional Prosedur (SOP) yang ada dalam pembuatan visum. Mempermudah proses perizinan pembuatan visum karena fungsi visum sangat penting dalam proses penegakan hukum. Membuat standardisasi pembuatan visum, dan Memperjelas aturan pendanaan untuk proses visum.

Sebagai penutup, SOP permintaan visum dimulai dengan surat resmi harus diterima oleh setiap rumah sakit dan dipermudah perizinan permintaan visum. Kemudian diproses dengan baik dengan menggunakan bahasa yang mudah dipahami oleh polisi. Dalam proses pembuatan sebaiknya diberlakukan standardisasi pembuatan visum yang berlaku di semua instansi kesehatan serta alur pembiayaan permintaan visum yang harus diperjelas.

\section{Daftar Pustaka}

1. Ranoemihardja A. Ilmu Kedokteran Kehakiman (Forensic Science). Edisi 1. Bandung: Tarsito; 1983. hlm. 18.

2. Sofyan A. Hukum Acara Pidana Suatu Pengantar. Edisi 1.Yogyakarta: Rangkang; 2012. hlm. 424 .

3. Atmasasmita R. Kapita Selekta Hukum Pidana dan Kriminologi. 1st edition. Bandung: Mandar maju; 1995. hlm.

4. Susanti R. Paradigma Baru Peran Dokter dalam Pelayanan Kedokteran Forensik. Journal of the Indonesian Medical. Padang; 2012;36(2):146-54.

5. Herkutanto. Peningkatan Kualitas Pembuatan Visum et Repertum (VeR) Kecederaan di Rumah Sakit Melalui Pelatihan Dokter Unit Gawat Darurat (UGD). Journal Manajemen Pelayanan Kesehatan (JMPK). 2005;08(03):163-9.

6. Afandi D. Visum et Repertum of Injury: Medicolegal Aspect and Determining Degree of Injury. Majalah Kedokteran Indonesia. 2011;60(4):188-195

7. Kementrian Pemberdayaan Perempuan dan Perlindungan Anak Tahun 2010 (Prosedur Standar Operasional Pelaksanaan Standar Pelayanan Minimal). Kementerian 
Pemberdayaan Perempuan dan Perlindungan Anak Republik Indonesia; 2010:h hlm 21555

8. Simpson K. Simpson's Forensic Medicine, 13th Edition. Great Britain. Hodder Arnold; 2011. h hlm. 216-35

9. Kitab Undang-Undang Hukum Acara Pidana ( KUHAP ) Undang-Undang Nomor 8 Tahun 1981. Jakarta. 1981 (diunduh Tanggal 12 agustus 2016); 23:15. Tersedia dari :http://www.jdih.kemenkeu.go.id/ fulltext/1981/8TAHUN 1981UU.HTM

10. KitabUndang-UndangHukumPidana(KUHP ). 1st edition. Jakarta: Bina Aksara; 1983 (diunduh 12 Agustus 2016); 23.00. Tersedia dari: https://www.tribunais.tl/files/Codigo Penal_Indonesio_(Bahasa_Indonesia).pdf

11. Menteri Hukum dan Hak Asasi Manusia Republik Indonesia (Peraturan Pemerintah Republik Indonesia Nomor 58 Tahun 2010 Tentang Pelaksanaan Kitab Undang-Undang Hukum Acara Pidana). Menteri Hukum dan Hak Asasi Manusia Republik Indonesia; 2010: 46

12. Nugraheni TD. Studi Mengenai Pelaksanaan Pembuktian Terhadap Kealpaan yang Menyebabkan Matinya Orang Lain di Pengadilan Negeri Surakarta. Fakultas Hukum Universitas Sebelas Maret Surakarta.
2007 (diunduh tanggal 12 November 2016); 12:50. Tersedia dari: eprints.uns. ac.id/2579/1/56931006200910201.pdf

13. Afandi D. Visum et Repertum Perlukaan : Aspek Medikolegal dan Penentuan Derajat Luka. Majalah Kedokteran Indonesia. 2010;60(4): 188.

14. Grisso T. Guidance for Improving Forensic Reports: A Review of Common Errors. Open Access J Forensic Psychol. 2010;2(c):10215.

15. Wells D. Guidelines for medico-legal care for victims of sexual violence. World Health. 2003 (diunduh Tanggal 24 November 2016); 15;50. Tersedia dari: http://whqlibdoc.who. int/publications/2004/924154628X.pdf

16. Ayunda P S Vinka. Faktor Keterlambatan Pelaksanaan Visum et Repertum di RSUD $\mathrm{Hj}$. Anna Lasmanah Banjarnegara. 2016 (diunduh 13 November 2016); 12:43. Tersedia dari: etd.repository.ugm.ac.id/ index.php?mod=penelitian_detail\&sub $=\mathrm{Pe}$ nelitianDetail\&act=view\& ty $\mathrm{p}=\mathrm{html} \&$ buku_ $\mathrm{id}=98803$ \&obyek $\mathrm{id}=4$

17. Undang-Undang $\bar{R}$ epublik Indonesia Nomor 36 Tentang Kesehatan. 2009 (diunduh Tanggal 24 November 2016); 23:00. 1-33. Tersedia dari:http://www.hukor.depkes.go.id/up prod_uu/UUNo.36Th2009 ttg Kesehatan.pdf 